\section{The beneficial effect of shareholder participation in general meetings: Evidence in the context of audit quality}

\author{
Ameneh Bazrafshan ${ }^{1}$ \\ Akram Banaiy ${ }^{1}$ \\ Vajiheh Bazrafshan ${ }^{1}$
}

\section{Abstract}

Purpose - This paper aims to investigate how shareholder participation in general meetings (SPGM) affects audit quality.

Design/methodology/approach - We measure SPGM as the percentage of the ownership represented by the shareholders who attend the general meeting. We measure audit quality by auditor industry specialization, audit firm size, and auditor fees. In order to investigate the relationship between SPGM and audit quality, we use a sample of 576 firm-years from Iran's capital market between 2012 and 2018 and employ multivariate regression analysis.

Findings - The findings show that, in general, there is an insignificant relationship between SPGM and audit quality. However, we reveal that there is a positive and significant association between the presence of institutional shareholders in general meetings and audit quality. Furthermore, for the companies with a high presence of institutional shareholders in their general meetings, there is a significant and positive relationship between the participation of other shareholders in the general meetings and audit quality. Our findings are robust in regards to a variety of additional tests.

Originality/value - Collectively, the findings reveal that the impact of SPGM on audit quality is conditional to the presence of institutional shareholders in general meetings. The findings provide further insights among the mixed evidence on the beneficial effects of SPGM.

Keywords - general meetings, audit quality, corporate governance, regulators, institutional shareholders

1. Imam Reza International University, Mashhad, Iran

How to cite:

Bazrafshan, A., Banaiy, A., Bazrafshan, V. (2021). The beneficial effect of shareholder participation in general meetings: Evidence in the context of audit quality. Revista Brasileira de Gestão de Negócios, 23(1), p.81-103.
Received on:

02/28/2019

Approved on:

09/04/2020

Responsible Editor:

Prof. Dr. Javier Montoya Del Corte

\section{Evaluation process:}

Double Blind Review

\section{Reviewers:}

The authors chose not to disclose the identities of the reviewers.

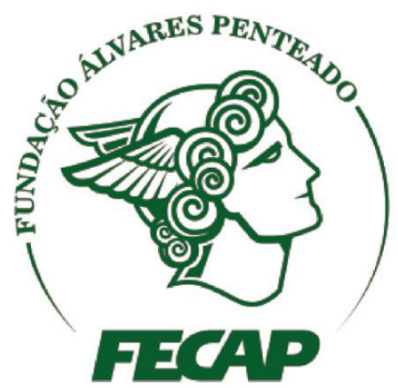

Revista Brasileira de Gestáo de Negócios

https://doi.org/10.7819/rbgn.v23i1.4096 


\section{Introduction}

Shareholder participation in general meetings (SPGM) is an important part of corporate governance in publicly-traded companies (e.g., Apostolides, 2010; Bebchuk, 2005; Krishnan \& Ye, 2005). Theoretically, higher SPGM is desirable, as it serves the interests of shareholders by giving them a stronger voice regarding important governance issues (Holland et al., 2021; Institutional Shareholder Services (ISS), 2016; SEC, 2018a; SEC, 2018b) and leads to a broader reflection of shareholders' interests in the corporate governance processes (e.g., ISS, 2016; Stratling, 2003). Furthermore, higher SPGM provides shareholders with a better opportunity to hold management accountable and may prevent managers from engaging in opportunistic behaviors (e.g., Mayhew \& Pike, 2004). For these reasons, regulators and securities commissions usually encourage higher SPGM (European Union, 2020; Institutional Shareholder Services, 2012; Krishnan \& Ye, 2005; U.S. Department of the Treasury, 2008). Nevertheless, several theoretical studies question the value of this higher SPGM (e.g., Jong, Mertens \& Roosenboom, 2006; Sjostrom, 2006). Moreover, the empirical research does not provide a lot of evidence on the beneficial effect of higher SPGM.

In this research, we focus on one of the potential consequences of higher SPGM: audit quality. Specifically, we examine how SPGM affects audit quality, defined as higher assurance that corporate reports reliably reflect the company's underlying economics (Defond \& Zhang, 2014). Theoretically, SPGM may reduce the influence of managers in the auditor selection and auditing processes (e.g., Advisory Committee on the Auditing Profession, 2008; ISS, 2016) and may therefore change the potential focus of the auditors from the managers' reporting preferences to the investors' reporting preferences (e.g., DoT, 2008; Hermanson, Krishnan, \& Ye, 2009; Lev, 2002; Tanyi \& Roland, 2017), resulting in higher audit quality. Moreover, SPGM serves as a monitoring device that influences auditors and their work (ISS, 2016; Krishnan \& Ye, 2005; Tanyi \& Roland, 2017) and may ensure that the choice of auditor meets the company's specific needs (e.g., ACAP, 2008; DoT, 2008; Federal Trade Commission - FRC, 2003), resulting in higher audit quality.

The motivation for this focus is based on the following facts. First, audit quality plays an important role in reducing agency conflicts between shareholders and managers and has substantial effects on a significant portion of subsequent discussions, decisions, and shareholder interests (e.g., Dao, Raghunandan, \& Rama, 2012; Defond \& Zhang, 2014). Hence, the concept is fundamental in itself.

Second, regulators are considering issuing recommendations to require all public companies to have a shareholder vote on auditor selection (e.g., Cunningham, 2017; Institutional Shareholder Services, 2015). To clarify, some professional bodies such as the UK Financial Reporting Council and the US Advisory Committee on the Auditing Profession argue that to ensure the auditors are suitable for the companies and corporate reporting needs, shareholder engagement in the selection and ratification of auditors through the general meeting should be considered (e.g., DoT, 2008; FRC, 2007). In this regard, the need for related empirical evidence is highlighted by calls for further research (e.g., Mayhew, 2017).

Third, there are international debates on the beneficial effect of shareholder engagement in auditor appointments and re-appointments (e.g., Cunningham, 2017; Dao et al., 2012). To clarify, on the one hand, shareholder engagement may lead to a broader reflection of shareholders' interests in audit quality and play an important role in reducing agency conflicts between investors and managers (e.g., Cohen, Krishnamoorthy, \& Write, 2010; Dao et al. 2012; Krishnan \& Ye, 2005). This is because in many companies the boards of directors (and audit committees) are dominated by management (e.g., Mayhew \& Pike, 2004) and, therefore, auditors' natural response is to be more likely to go along with managements' preferred accounting choices (Cohen et al., 2010; KPMG, 2004). On the other hand, the majority of voters may not have sufficient knowledge about the quality of the auditors and therefore the majority of votes may be reflective of factors (such as stock returns achieved in the period leading up to the vote) that are outside the auditor's scope (e.g., Cunningham, 2017; Liu, Raghunandan, \& Rama, 2009). This is particularly relevant when many audit characteristics are only partially observable (Fontaine, Leteifa, \& Herda, 2013).

Fourth, while there is theoretical and experimental evidence indicating that SPGM may influence audit quality (e.g., Dao et al. 2012; Lev, 2002; Stewart \& Munro, 2007), empirical evidence on the association between SPGM and audit quality is rare, especially in emerging capital markets. For example, while prior experimental 
research indicates that SPGM may influence auditor selection and therefore SPGM may lead to higher audit quality, such research significantly simplifies the research setting (Mayhew \& Pike, 2004), and thus the experimental methodology may deviate from realism (e.g., Swieringa $\&$ Weick, 1982). Moreover, the studies usually focus on developed capital markets, where, on the one hand, there are various information channels that may provide more extensive information besides audited reports ( $\mathrm{Su}$, Peng, Tan, \& Cheung, 2014), and therefore the importance of auditing is lower. On the other hand, there are various institutional settings that help shareholders to prevent manager influence in the auditing process and to monitor and control the audit quality. This is particularly relevant, as managerial discretion in emerging markets is relatively higher than in developed capital markets (e.g., Hesarzadeh, 2019; 2020). For these reasons, the related literature (e.g., Krishnan \& Ye, 2005) mentions the need for research outside developed countries.

Our sample includes listed companies in Iran's capital market. As we will discuss in the "Sample and data" section, this is an appropriate research setting, particularly because in Iran, consistently with the research question, all listed companies must conduct an annual selection of the external auditor through the annual meeting and proxy process (e.g., Sajadi, Farazmand, \& Gorbani, 2012). To clarify, consistently with Iran's Commercial Law and Regulations Governing the Trusted Auditing Firms of the Securities and Exchange Organization (Islamic Consultative Assembly, 1979; Securities and Exchange Organization, 2007a), in general meetings, shareholders elect and appoint the auditors through a voting process.

Our findings show that, in general, there is an insignificant association between SPGM and audit quality. However, we find that (a) there is a positive and significant association between the presence of institutional shareholders in general meetings and audit quality, and (b) for the companies with a high presence of institutional shareholders in their general meetings, there is a significant and positive relationship between the participation of other shareholders in the general meetings and audit quality. Thus, collectively, the findings propose that the impact of SPGM on audit quality is conditional to the presence of institutional shareholders in general meetings.

The findings contribute to the literature on both SPGM and audit quality in several ways. To clarify, first, this study reveals evidence on the beneficial effect of higher SPGM in an emerging capital market. Second, the study introduces SPGM as a positive determinant of audit quality, when the presence of institutional shareholders in general meetings is high. More broadly, the study adds to the international debate over whether SPGM enhances corporate governance (e.g., Cunningham, 2017; Sjostrom, 2006; Strand, 2013).

The next section presents the background and develops the research hypotheses. This is followed by the presentation of the research method, the empirical results, and, finally, the conclusions.

\section{Background and hypotheses development}

\section{I Shareholder participation in general meetings}

Modern companies are characterized by the separation of ownership from management. This separation leads to a further need for the practical mechanisms of corporate governance to ensure that resources are efficiently and effectively used (Velury, Reisch, \& O’Reilly, 2003). In this regard, SPGM is a basic and an essential part of corporate governance (Bebchuk, 2005; Proctor \& Miles, 2003).

To clarify, annual general meetings are an appropriate platform that enables shareholders to hold managers accountable and, thus, annual general meetings constrain the possibility of shareholder expropriation by managers (Stratling, 2003). Apostolides and Boden (2005) stress the importance of general meetings as a corporate governance mechanism. This is because, first, general meetings are forums where shareholders are informed about substantial company matters and they consequently have an opportunity to exercise their control over managers and to participate in the diverse decision-making processes. Second, general meetings provide rare occasions in which diverse stakeholders in a company come together in one place to have their discussions about firm governance and other important matters (Apostolides, 2010). Third, the meetings also provide an instrument of checks and balances, where managers have to explain themselves to shareholders and where the latter may take corrective actions by exercising their ownership rights (Beuthel, 2006; Daniel, 2010; Stratling, 2003).

Related empirical research, while relatively rare, generally reveals that general meetings provide effective means for shareholders to communicate with managers, 
and managers usually take corrective actions in response to shareholder votes (Yermack, 2010). For instance, Bebchuk and Cohen (2005), Faleye (2007), and Gompers, Ishii, and Metrick (2009) highlight the effects of voting restrictions on firm performance and firm value, and suggest that firms perform worse when the shareholder franchise is curtailed due to structures such as a classified board. Cai, Garner, and Waking (2009) and Fischer, Gramlic, Mille, and White (2009) document that meaningful votes against the election of certain directors are followed by changes in the management or corporate actions within the next year. Particularly, Cai et al. (2009) find that votes against the reelection of independent directors increase the probability of CEO turnover in the next year, holding constant the effects of corporate performance and other variables.

General meetings are probably more important in emerging capital markets. This is because, on the one hand, there is considerable information asymmetry between shareholders and managers (Bhattacharya, Desai, \& Venkataraman, 2013; Hesarzadeh, 2019). On the other hand, the diversity of information channels/resources are not comparable to developed capital markets (Su et al., 2014); and as a result of relatively weak supervisory mechanisms, the managerial discretion in emerging markets is relatively higher than in developed capital markets (Hesarzadeh, 2019). In this regard, Sjostrom (2006) states that executive managers may be less inclined to engage in opportunistic behavior or shirk responsibilities if they know that they have to explain themselves to shareholders face-to-face and suffer the resulting embarrassment.

Theoretically, higher SPGM is desirable for stakeholders, especially shareholders (e.g., Krishnan \& Ye, 2005). This is because higher SPGM leads to a broader reflection of shareholders' interests in the corporate governance processes. To clarify, higher SPGM is equivalent to the situation in political democracies, as a higher rate of voter participation leads to a better reflection of citizens' views in the governance of the country (Seeger, 2002). Furthermore, a higher rate prevents a specific interest group - that only constitutes a small portion of the population - from hijacking the democratic process to its advantage (Latham, 2003). Similar reasoning may be applied to the process of decision-making at general meetings (Beuthel, 2006). If only a small portion of shareholders participates in a general meeting, then a group that only holds a small portion of ownerships will have significant influence in the governance of the company, resulting in the possibility of expropriation of the company and major shareholders by a small group of shareholders.

For the reasons mentioned above, regulators and securities commissions are now looking for ways to encourage more shareholders to participate in their general meetings (Institutional Shareholder Services, 2012; Krishnan \& Ye, 2005; U.S. Department of the Treasury, 2008).

In contrast with the discussions above, several studies question the importance and value of general meetings (e.g., Jong et al., 2006; Sjostrom, 2006; Stratling, 2003). Moreover, they call for the requirements for general meetings to be phased out (Stratling, 2003; Sjostrom, 2006). For example, based on a study of annual general meetings in the Netherlands, Jong et al. (2006) conclude that general meetings do not provide shareholders with a significant beneficial effect. Furthermore, Sjostrom (2006) suggests that general meetings are both worthless and costly and should therefore not be mandated annually. In this regard, the literature (e.g., Jong et al., 2006; Sjostrom, 2006; Strand, 2013; Stratling, 2003) argues that annual general meetings are an outdated practice, which made more sense when ownership was less dispersed, shareholders were more concentrated in a local geographic area, the practice of proxy voting had not yet been developed, and communication technology was primitive. Under those circumstances, attendance was likely to be higher, providing shareholders with the opportunity to nominate competing proposals - an opportunity that is non-existent today as no shareholder body exists due to low attendance rates (Stratling, 2003). Sjostrom (2006) also criticizes general meetings for being overly controlled by executive managers. Furthermore, Strand (2013) argues that general meetings are altogether redundant in the effective exercise of agency relationships, and that the meetings often fail to achieve their legitimate purposes due to minority shareholders turning the meetings into a chaotic shambles (Saxon, 1966). In addition, the existence of issues such as staggered boards, or plurality voting/the difficulty of proxy fights, not paying attention to the concerns of small shareholders, the absence of directors, and also low shareholder participation in general meetings, may serve to decrease the importance and value of such meetings (e.g., Banko, Frye, Wang \& Whyte, 2013; González, Guzmán, Prada, \& Trujillo, 2013; Strand, 2013). Particularly, votes cast by uninformed shareholders probably constrain the ability of proxy voting to work as an effective governance 
tool. In this regard, Lund (2019) advocates for the issuance of non-voting shares as a mechanism to encourage voters who do not wish to incur the costs of becoming informed to opt out of the voting process.

The competing perspectives indicated above highlight the need to provide further empirical evidence on the beneficial effect of higher SPGM.

\subsection{Audit quality}

Auditing provides independent assurance of the reliability of corporate information, which enhances both the allocation of corporate resources and the efficiency of corporate contracts (Chen, He, Ma, \& Stice, 2012). The increasing complexity of business and reporting standards extends the potential of auditing to add value. That is why audit quality is crucial in the business context (Defond \& Zhang, 2014).

While some studies define audit quality as some variation of "the market-assessed joint probability that a given auditor will both detect a breach in the client's accounting system, and report the breach" (DeAngelo, 1981, p. 115), Defond and Zhang (2014) argue that this definition understates the benefits of high audit quality, which extend well beyond the simple detection and reporting of GAAP violations. Thus, they define audit quality as the higher assurance that the corporate reports reliably reflect the company's underlying economics (Defond \& Zhang, 2014). The notion that the auditor's responsibility extends to assuring financial reporting quality is consistent with generally accepted auditing standards, which require auditors to evaluate financial reporting quality (PCAOB, 2010). Furthermore, the aforementioned assurance reduces information risk, which ultimately improves resource allocation and contracting efficiency (e.g., Liu, Cullinan, \& Zhang, 2018).

Nevertheless, regarding auditors' responsibilities and audit quality, prior literature (e.g., European Commission, 2010; Porter, Ó hÓgartaigh, \& Baskerville, 2012; Ruhnke \& Schmidt, 2014; Vanstraelen, Schelleman, Meuwissen, \& Hofmann, 2012) argues that there is a big expectation gap among different stakeholders, especially between shareholders and management. For example, Ruhnke and Schmidt (2014) suggest that, in contrast to shareholders, supervisory board members and executive managers disagree that evaluating the propriety of the management's adoption of the going concern assumption is auditors' current responsibility. More importantly, they state that, in contrast to shareholders, supervisory board members and executive managers disagree that audit reports should have stronger information content. Relatedly, Vanstraelen et al. (2012) find that shareholders are interested in providing more information about audit findings, including those relating to critical accounting estimates and management judgments.

In addition to these expectation gaps between shareholders and management, managers may have strong incentives to influence the audit process (e.g., O'Connor, 2002; Stewart \& Munro, 2007), especially if they seek personal benefits (Beck \& Mauldin, 2014).

For these reasons, in recent decades, regulators have made audit committees formally responsible for the selection and compensation of external auditors (e.g., Mayhew \& Pike, 2004; Turley \& Zaman, 2004). However, evidence (e.g., Mayhew \& Pike, 2004; Stewart $\&$ Munro, 2007) indicates that even in the presence of audit committees, managers continue to exert significant control over the hiring and firing of auditors. Particularly, prior studies using surveys and interviews (e.g., Beattie, Fearnley, \& Brandt, 2000; Cohen, Krishnamoorthy, \& Wright, 2002; Gibbins, McCracken, \& Salterio, 2005) all suggest that the audit committee is not being used to its full potential in auditor-management negotiations and, hence, there is a need for a new system where shareholders have further power over the hiring and firing of auditors.

\subsection{SPGM and audit quality}

Professional bodies such as the UK Financial Reporting Council and the US Advisory Committee on the Auditing Profession strongly suggest that SPGM enhances audit quality (e.g., DoT, 2008; FRC, 2007). This is because, generally, the traditional view of professional bodies is that SPGM reduces the influence of managers in the auditor selection and auditing processes, and therefore SPGM leads to higher audit quality (Advisory Committee on the Auditing Profession, 2008; European Union, 2006; Federal Trade Commission, 2003; ISS 2016). For example, the Advisory Committee on the Auditing Profession states that if executive managers have major influences on auditors, the auditors will more probably follow the preferences of the executive managers (DoT, 2008). Moreover, the Reputation Institute (2015) reports that higher SPGM indicates that the active eyes of public monitors evaluate audit performance to a greater extent. In fact, higher SPGM leads to a broader reflection of 
shareholders' interests in the auditor selection processes (Krishnan \& Ye, 2005). This is probably because, by exerting voting rights, on the one hand shareholders have the power to influence the characteristics of the audit, and on the other hand auditors receive significant feedback concerning the shareholders' views on the auditor and the service provided (Tanyi \& Roland, 2017). In this respect, Hermanson, Krishnan, and Ye (2009) argue that votes are an appropriate way for shareholders to signal their views on the audit quality provided by the incumbent auditors.

In the academic literature, there is little archival empirical evidence on the association between SPGM and audit quality. However, theoretical, survey, and experimental research provides some insights into this issue. For example, Kahneman and Tversky (1979) theoretically discuss the idea that SPGM changes the focus of auditors from the managers' reporting preferences to the investors' reporting preferences. To clarify, in the client (firm)-supplier (auditors) relationship, on the one hand, auditors are obligated to serve their clients' needs - possibly allowing aggressive reporting practices. In this regard, Cohen et al. (2010) find that auditors perceive executive managers as the "key driver" of auditor selection. Furthermore, recent archival empirical literature (e.g., Dhaliwal, Lamoreaux, Lennox, \& Mauler, 2015; Park, 2018; Tanyi \& Cathey, 2020) concludes that management has continued to have a significant impact on auditor selection during the post-SOX period. For example, Dhaliwal et al. (2015) suggest that management affiliation (defined as a prior working relationship between a management member and a Big4 auditing firm) significantly affects auditor selection. For example, they show that Ernst \& Young (EY) is appointed 29 percent of the time when there is no affiliation between the company's management and EY. In contrast, $\mathrm{EY}$ is appointed 61 percent of the time when there is a management affiliation with EY. Furthermore, Tanyi and Cathey (2020) highlight that the CEO's myriad of personal connections and influence with members of the audit committee circumvent the independence of auditors. In a pessimistic view, auditors "tend to kowtow instead to the managers who choose them and dole out their pay" (Hilzenrath, 2001, p. 2). On the other hand, audit committees, who have responsibilities for the selection and oversight of external auditors, have incentives to support management's preferences that outweigh liability-related incentives (Abbott \& Parker, 2000). The popular press can provide examples of auditors being fired for disagreeing with clients or issuing modified opinions (Mayhew \& Pike,
2004). That is why nearly every independence debate has centered on the concern that auditors may evolve into client advocates (Mayhew \& Pike, 2004). Others have cited the relationship between auditors and their clients as a core independence problem, calling for a change from client management choosing auditors to a system where investors make the decision (e.g., Lev, 2002).

Relatedly, survey literature (e.g., Cohen et al., 2002; Gibbins, Salterio, \& Webb, 2001; Stewart \& Munro, 2007) argues that audit committees play a less important role in the audit process than senior management. Particularly, the literature suggests that audit committees are largely ceremonial (Beasley, Carcello, Hermanson, \& Neal, 2009; Cohen et al., 2002; Cohen et al., 2010). For example, based on structured interviews with auditors, Cohen et al. (2002) find that audit committees have no significant role in the audit process. Particularly, audit committees are ineffective and lack sufficient power to withstand pressure from management. Similarly, both Gibbins et al. (2001) and Gibbins et al. (2005) find that audit committees only occasionally play an important role in the auditor-client negotiation process; while, after conducting in-depth interviews with auditors, Beattie et al. (2000) report that auditors do not experience significant support from audit committees.

In line with the concerns above, Mayhew and Pike (2004) state that higher shareholder involvement in auditor selection strengthens the power of the auditor in any negotiations with management and increases the "pressure to perform" on the auditor. Furthermore, if auditors are likely to be more careful to avoid the possibility of any criticism by shareholders who are involved in the auditor selection and ratification process, then it is likely that auditors would make extra effort and be more cautious in negotiations with the client, both of which would likely lead to higher audit quality (Dao et al., 2012).

The positive effects of shareholder involvement in auditor selection are also supported by some experimental studies. For example, Barua, Raghunandan, and Rama (2017) show that more votes on the auditor reduce the probability of subsequent auditor dismissals. Furthermore, in an experimental setting, Mayhew and Pike (2004) show that investor involvement in auditor selection may lead to higher audit fees and audit quality. Relatedly, Dao et al. (2012) highlight that higher shareholder involvement in the selection of auditors may improve the accountability and governance dynamics between shareholders, auditors, and mangers, and thus the higher involvement may lead 
to higher audit quality. Furthermore, Liu et al. (2009) reveal that higher SPGM is more probably associated with auditor dismissal following poor corporate reporting. Thus, based on the discussions above, our first research hypothesis is as follows:

H1a: There is a positive relationship between SPGM and audit quality.

In contrast to our discussions above, if shareholders cannot understand audit quality, then we expect to observe an insignificant (or even negative) association between SPGM and audit quality. Specifically, the majority of voters may not have sufficient knowledge about the quality of the auditors (e.g., Kaniel, Saar, \& Titman, 2008), and therefore the majority of votes may be reflective of factors (such as stock returns achieved in the period leading up to the vote) that are outside the auditor's scope (e.g., Cunningham, 2017; Liu, Raghunandan, \& Rama, 2009). Several past studies (Brown \& Cliff, 2004; Cunningham, 2017; Kaniel et al. 2008) provide support for investors having such a myopic focus. Hence, in contrast to $H 1 a$, our research hypothesis $H 1 b$ is as follows:

H1b: There is no relationship between SPGM and audit quality.

Consistent with the concern above, past literature (e.g., Aggarwal, Saffi, \& Sturgess, 2015; Cassell et al., 2019) indicates that institutional shareholders strongly consider, understand, and therefore demand higher audit quality. This is because institutional shareholders tend to facilitate their monitoring activities (Velury et al., 2003). Particularly, auditing literature suggests that audit quality is different across audit firms (e.g., Schauer, 2001), and the demand for a high quality audit is a function of the company's ownership base, in the sense that firms with sophisticated investors will probably hire audit firms that are providers of higher audit quality. Particularly, Velury et al. (2003) suggest that companies with higher active institutional ownership more probably employ industry specialist audit firms. Therefore, in companies with a higher presence of institutional shareholders in general meetings (PISGM), the quality of the auditor selection process in general meetings is higher.

Nonetheless, the increasing role of institutional shareholders has raised concerns about their investment strategies. This is because institutional shareholders have strategic alliances and strategic connections with management, meaning high-quality audits are not considered a priority. In this regard, Adeyemi and Fagbemi (2010) find that there may be a negative relationship between institutional ownership and audit quality.

Considering the discussion above, we state our second hypothesis as follows:

H2: There is a significant relationship between PISGM and audit quality.

Based on prior literature (e.g., Attig, Ghoul, \& Guedhami, 2009; Attig, Ghoul, Guedhami, \& Rizeanu, 2013; Attig, Guedhami, \& Mishra, 2008; Bennedsen \& Wolfenzon, 2000; Boubaker, Nguyen, \& Rouatbi, 2016), large management shareholders could influence general meetings to extract private benefits of control at the expense of other shareholders. This is particularly relevant for emerging markets in which there is a large ownership concentration (e.g., Barontini \& Caprio, 2006; Hu \& Izumida, 2008; Villalonga, Amit, Trujillo, \& Guzmán, 2015) and agency conflicts between the largest shareholders and others are high (e.g., Chrisman, Chua, $\& \mathrm{Liz}, 2004)$. For example, the controlling shareholder and management in such an environment are likely to expropriate the minority shareholders and inflate earnings to gain private benefits (Bae et al. 2002).

In this regard, corporate governance literature (e.g., Rossi, Barth, \& Cebula, 2018; Cassell et al., 2019) reveals that PISGM may heavily reduce agency costs. This is because PISGM causes shareholder activism when non-controlling shareholders are not very satisfied with some features of governance (Shleifer \& Vishny, 1986). To clarify, institutional shareholders may reduce the dispersion of control from minority shareholders by forming coalitions among non-controlling shareholders (e.g., Basu, Paeglis, \& Rahnamaei, 2016). Bloch and Hege (2003) formulate a theoretical model to argue that the coalitions decrease agency costs. Furthermore, Rossi et al. (2018) empirically show that coalitions among shareholders significantly contribute to a reduction of agency costs as the coalitions probably give shareholders a stronger voice regarding important governance issues and could lead to a broader reflection of their interests in corporate governance processes. In these conditions, the influence of managers in auditor selection is reduced and therefore audit quality is improved (Gotti, Han, Higgs, \& Kang, 2012). For this reason, we expect PISGM to strengthen the impact of the participation of other shareholders in general meetings (hereafter, POSGM) on audit quality.

Based on the discussion above, we state our third hypothesis as follows: 
H3: PISGM moderates the relationship between POSGM and audit quality.

\section{Method}

\section{I Empirical models}

Consistently with the first hypotheses, our main independent variable is $S P G M$. This study measures $S P G M$ as the percentage of shareholder attendance at annual general meetings. Specifically, SPGM is the percentage of the ownership represented by the shareholders who attend the general meeting. Furthermore, consistently with the second and third hypotheses, our main independent variables are PISGM and POSGM. Similarly to SPGM, we measure PISGM as the percentage of the ownership represented by the institutional shareholders who attend the general meeting. We define POSGM as SPGM minus PISGM.

Moreover, in all hypotheses, our dependent variable is audit quality. The most common approach to measuring audit quality is to focus on the inputs of the audit processes, including auditor industry specialization, size, and fees (e.g., Defond \& Zhang, 2014). These inputs are very appealing, especially in our research. This is because shareholders usually choose audit quality according to the observable inputs. Furthermore, in the financial literature, the research studying the effects of demandside variables usually employs input-based measures of audit quality (e.g., Defond \& Zhang, 2014). Thus, we measure audit quality by auditor industry specialization, audit firm size, and audit fees.

To test the first hypothesis (including $H 1 a$ and $H 1 b$ ), we follow past research (i.e., Bebchuk, 2005; Chen et al., 2012; Defond \& Zhang, 2014) and use multivariate regression analyses. Specifically, to test the first research hypothesis, i.e., the relationship between SPGM (SPGM) and audit quality, we rely on the multivariate estimations of equations (1) to (3), where we use as a proxy for audit quality auditor industry specialization ( $A u d I n d S p c)$, audit firm size (AFSize), and audit fees (AFees).

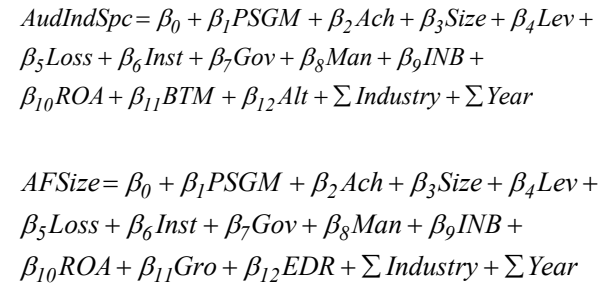

$$
\begin{aligned}
& \text { AFees }=\beta_{0}+\beta_{1} P S G M+\beta_{2} \text { Ach }+\beta_{3} \text { Size }+\beta_{4} \text { Lev }+ \\
& \beta_{5} \text { Loss }+\beta_{6} \text { Inst }+\beta_{7} \text { Gov }+\beta_{8} \text { Man }+\beta_{9} \text { INB }+ \\
& \beta_{10} \text { ROA }+\beta_{11} \text { FS }+\beta_{12} \text { Seg }+ \text { IIndustry }+\sum \text { Year }
\end{aligned}
$$

In the equations above, AudIndSpc is the auditor's expertise in the industry and is measured by the market share of the audit firms. Specifically, if the market share of the audit firm is higher (lower) than $1.2 \times(1 \div$ the number of companies in the industry-year), we coded the variable as one (zero). The market share is the total assets of all clients of each audit firm in an industry-year divided by the total assets of all companies in the same industry-year. AFSize is a dichotomous variable coded as one if the company is audited by a big audit firm, and zero otherwise. Finally, AFees is the natural logarithm of audit fees.

Based on past literature (e.g., Amir, Guan, \& Livne, 2018; Bae et al., 2019; Bebchuk, 2005; Chen et al., 2012; Defond \& Zhang, 2014; Engel, Hayes, \& Wang, 2010; Minutti-Meza, 2013; Patterson et al., 2019), the equations above also include diverse control variables which affect the dependent variables. These control variables are defined as follows. Ach is a dichotomous variable coded as one if the auditor is changed, and zero otherwise. Size is the size of the company and is equal to the logarithm of total assets. Lev is the total liabilities divided by total assets. Inst is the percentage of institutional ownership (i.e., the percentage of shares held by banks, insurance companies, pension funds, and investment companies). Gov is the percentage of shares held by the government. Man is the percentage of shares held by the managers. Loss is a dichotomous variable coded as one if net income is negative, and zero otherwise. INB is the independence of the board of directors, calculated as the number of non-executive directors divided by the total number of directors. $R O A$ is the net income divided by total assets. $B T M$ is the book value of equity divided by the market value of equity. Alt is the Altman (1983) financial distress score. The score is coded as one if it is greater than the median and zero otherwise. Gro is the percentage of sales growth. FIN is a dichotomous variable coded as one if there is equity/debt issuance. FS is the foreign sales divided by total assets. Seg is the natural logarithm of the number of segments. EIndustry reflects industry fixed effects. $\sum$ Year reflects year fixed effects (Appendix A presets the definitions of all variables).

Furthermore, to test the second research hypothesis, i.e., there is a significant relationship between PISGM 
and audit quality, we use equations 1 to 3 above, after replacing SPGM with PISGM.

Finally, to test the third research hypothesis, i.e., PISGM moderates the relationship between POSGM and audit quality measures, we divided our sample into two sub-samples: (a) firm-years with high PISGM and (b) firm-years with low PISGM. To clarify, for example, we classify a firm-year into sub-sample (a) when the PISGM in each year is greater than the median. Then, we re-estimate equations 1 to 3 in both sub-samples (a) and (b), after replacing SPGM with POSGM (measured as SPGM minus PISGM). In the "Additional analyses" section, we rerun this analysis using regressions with an interaction term.

\subsection{Sample and data}

Our sample consists of all firms in Iran's capital market, namely, the Tehran Stock Exchange (TSE), from 2012 to 2018. The TSE is an appropriate research setting, because, first, and consistently with the research question, all companies listed on the TSE must carry out an annual selection of the external auditor through the annual meeting and proxy process (e.g., Sajadi et al., 2012). In this respect, consistently with Iran's Commercial Law and Regulations Governing the Trusted Auditing Firms of the Securities and Exchange Organization (Islamic Consultative Assembly, 1979; Securities and Exchange Organization, 2007a), shareholders elect, appoint, and dismiss the auditors through a voting process. It is worth stating that shareholders can vote on a variety of different auditors, including an auditor that was proposed by the audit committee or other auditors that were not previously proposed by the audit committee. Furthermore, listed companies are required to publish content and decisions of general meetings (including decisions on auditor selection) online following their annual general meetings (Securities and Exchange Organization, 2007b).

Second, consistently with the research motivation, the TSE is an emerging market. In this regard, the TSE is comparable to most large developing capital markets in terms of basic market infrastructure (Hesarzadeh \& Bazrafshan, 2019; Hesarzadeh \& Rajabalizadeh, 2020). For example, in recent decades, Iran has used international accounting/auditing standards as a foundation for setting its national standards (Mashayekhi \& Mashayekh, 2008). Furthermore, past research (e.g., Paytakhti Oskooe, 2011) shows that the TSE is efficient in a weak form.
This paper obtains the SPGM and PISGM data from CODAL, the Comprehensive Database of All Listed Companies in Iran. The paper obtains other data from Rahavard-e-Novin, the most comprehensive database in Iran's capital market (Hesarzadeh, 2019). We exclude firm-years with insufficient data to measure our variables. Furthermore, for more consistency among companies, particularly consistency in the timing of general meetings, we exclude firm-years with a nonEsfand (April) fiscal year-end. Our final sample consists of 574 firm-year observations, including 82 firms over the seven years.

\section{Results}

\section{I Descriptive statistics}

Descriptive statistics for the variables are presented in Table 1. To minimize the impact of extreme data on the findings, the variables are winsorized at the extreme one percent. In this regard, the mean value for SPGM is about $82 \%$, indicating that, on average, $82 \%$ of shareholders attended the annual general meetings. More specifically, the percentage of the ownership represented by the shareholders who attend the general meeting is $82 \%$. Moreover, PISGM is about $23 \%$, indicating that the percentage of the ownership represented by the institutional shareholders who attend the general meeting is $23 \%$. In addition, the mean value for the audit quality measures, including audit industry specialization ( $A u d I n d S p c$ ), audit firm size (AFSize), and audit fees (AFees), are 0.660, 0.712, 3.843, and 2.869, which are comparable to prior research (e.g., Louis, 2005; Mansi, Maxwell, \& Miller, 2004; Mayhew \& Pike, 2004; Venkataraman et al., 2008). Moreover, the measures indicate that the audit quality in our sample is similar to in large developing capital markets, but relatively lower than in developed capital markets (see for example, Chen, Su, \& Wu, 2010; Engel et al., 2010; Chen et al., 2012). In addition, the table shows that the average for institutional ownership (Inst) is approximately 0.316, indicating that about $31 \%$ of ownership in our sample belongs to banks, insurance companies, pension funds, and investment companies, which is comparable to large capital markets (e.g., Bebchuk, Cohen, \& Hirst, 2017). An untabulated analysis indicates that the average variance inflation factor (VIF) for the variables is approximately 1.5 , and none of the VIFs are higher than 3. 
Table 1

\section{Descriptive statistics}

\begin{tabular}{|c|c|c|c|c|c|c|}
\hline Variable & Obs & Mean & Median & Min & Max & Std. Dev. \\
\hline$S P G M$ & 574 & 82.347 & 84.100 & 0.083 & 1.000 & 13.758 \\
\hline PISGM & 574 & 23.069 & 25.983 & 0.000 & 68.015 & 4.051 \\
\hline$A u d I n d S p c$ & 574 & 0.660 & 1.000 & 0.000 & 1.000 & 0.627 \\
\hline AFSize & 574 & 0.712 & 1.000 & 0.000 & 1.000 & 0.681 \\
\hline AFees & 574 & 2.869 & 2.826 & 1.379 & 3.982 & 0.360 \\
\hline Ach & 574 & 0.212 & 0.000 & 0.000 & 1.000 & 0.254 \\
\hline Size & 574 & 5.992 & 5.927 & 4.452 & 7.852 & 0.625 \\
\hline$L e v$ & 574 & 0.372 & 0.376 & 0.098 & 2.165 & 0.213 \\
\hline Loss & 574 & 0.091 & 0.000 & 0.000 & 1.000 & 0.265 \\
\hline Inst & 574 & 0.316 & 0.346 & 0.000 & 0.731 & 0.301 \\
\hline Gov & 574 & 0.084 & 0.013 & 0.000 & 0.765 & 0.141 \\
\hline Man & 574 & 0.118 & 0.172 & 0.000 & 0.185 & 0.150 \\
\hline$I N B$ & 574 & 0.623 & 0.600 & 0.000 & 1.000 & 0.239 \\
\hline$R O A$ & 574 & 0.185 & 0.158 & -0.017 & 0.296 & 0.216 \\
\hline$B T M$ & 574 & 0.231 & 0.293 & 0.0101 & 0.871 & 0.381 \\
\hline Alt & 574 & 0.519 & 1.000 & 0.000 & 1.000 & 0.491 \\
\hline$G R O$ & 574 & 0.211 & 0.178 & 0.015 & 0.412 & 0.312 \\
\hline FIN & 574 & 0.295 & 0.000 & 0.000 & 1.000 & 0.198 \\
\hline$F S$ & 574 & 0.057 & 0.041 & 0.000 & 0.710 & 0.451 \\
\hline $\mathrm{Seg}$ & 574 & 2.602 & 2.302 & 0.000 & 2.944 & 1.003 \\
\hline
\end{tabular}

Table 2

The association between SPGM and audit quality

\begin{tabular}{|c|c|c|c|c|c|c|}
\hline \multirow{2}{*}{ Variable } & \multicolumn{2}{|c|}{ AudIndSpc } & \multicolumn{2}{|c|}{ AFSize } & \multicolumn{2}{|c|}{ AFees } \\
\hline & Coefficient & Prob. & Coefficient & Prob. & Coefficient & Prob. \\
\hline Intercept & $-10.651^{* * *}$ & 0.000 & $-3.504^{*}$ & 0.064 & -0.064 & 0.659 \\
\hline SPGM & -0.016 & 0.289 & 0.007 & 0.376 & 0.008 & 0.342 \\
\hline Ach & $-0.542^{* * *}$ & 0.008 & $-0.412^{* *}$ & 0.035 & $-0.136^{*}$ & 0.087 \\
\hline Size & $1.995^{* *}$ & 0.004 & $0.714^{* * *}$ & 0.000 & $0.562^{* * *}$ & 0.000 \\
\hline Lev & -0.872 & 0.212 & -0.350 & 0.783 & 0.079 & 0.254 \\
\hline Loss & -0.374 & 0.351 & $0.678^{* *}$ & 0.014 & $0.098^{* *}$ & 0.036 \\
\hline Inst & -0.419 & 0.461 & -0.078 & 0.943 & -0.016 & 0.894 \\
\hline Gov & $-8.741^{* * *}$ & 0.000 & $-0.098^{*}$ & 0.604 & $-0.324^{* * *}$ & 0.000 \\
\hline Man & -0.521 & 0.337 & $0.563^{*}$ & 0.097 & 0.042 & 0.423 \\
\hline$I N B$ & 0.108 & 0.664 & -0.491 & 0.188 & $-0.089^{*}$ & 0.072 \\
\hline$R O A$ & $-0.029^{*}$ & 0.081 & 0.019 & 0.223 & $-0.009^{*}$ & 0.083 \\
\hline$B T M$ & 0.074 & 0.426 & - & - & - & - \\
\hline Alt & 0.167 & 0.100 & - & - & - & - \\
\hline$G R O$ & - & - & $-0.042^{* *}$ & 0.045 & - & - \\
\hline FIN & - & - & 0.056 & 0.387 & - & - \\
\hline$F S$ & - & - & - & - & $0.326^{* *}$ & 0.037 \\
\hline Seg & - & - & - & - & $0.620^{* * *}$ & 0.008 \\
\hline EIndustry & Yes & & Yes & & Yes & \\
\hline$\sum Y e a r$ & Yes & & Yes & & Yes & \\
\hline Pseudo (adjusted) $\mathrm{R}^{2}$ & 0.433 & & 0.682 & & 0.829 & \\
\hline LR/F (Prob.) & $798.432(0.000)$ & & $714.105(0.000)$ & & $79.465(0.000)$ & \\
\hline
\end{tabular}




\subsection{Inferential Statistics}

Table 2 presents the results regarding the statistical test of $H 1$ (including $H 1 a$ and $H 1 b$ ). $H 1$ generally focuses on the relationship between SPGM (as measured by $S P G M$ ) and audit quality (as measured by AudIndSpc, AFSize, AFees). Based on the results, the coefficients of $S P G M$ are not statistically significant at the 0.1 level ( $\mathrm{p}$-value $=0.289,0.376,0.342)$. This suggests that, (in) consistently with $(H 1 a) H 1 b$, there is no meaningful relationship between SPGM and audit quality. This is consistent with prior literature (e.g., Cunningham, 2017; Liu et al., 2009) that indicates that the majority of voters may not have sufficient knowledge about the quality of the auditors, and therefore the majority of votes may be reflective of factors that are outside the auditor's scope. The coefficients of some of the common control variables, including Ach, Size, and Gov, are statistically significant. In this regard, the results suggest that audit quality is lower when the auditor is changed. Furthermore, the audit quality is lower for companies with a smaller size and higher levels of governmental ownership. In addition, the coefficients of some of the specific control variables, including $G R O, F S$, and $S e g$, are statistically significant. Specifically, the results indicate that audit firm size is lower when sales growth is higher. Moreover, the level of audit fees is higher for companies with equity or debt issuances and companies with higher numbers of segments.

Table 3 presents the results regarding the statistical test of $H 2$. $H 2$ predicts that there is a significant association between PISGM (as measured by PISGM) and audit quality (as measured by AudIndSpc, AFSize, AFees). Based on the results, the coefficients (Coef. $=0.058,0.012,0.063$ ) of SPGM are positive and statistically significant at the 0.1 level $(p$-value $=0.289,0.376,0.342)$. This suggests that there is a positive association between PISGM and audit quality. As a result, the second hypothesis is confirmed. This is consistent with prior literature (e.g., Velury et al. 2003) that suggests that companies with higher active institutional ownership are more likely to employ highquality audit firms.

Table 4 shows the results regarding the statistical test of $H 3$. $H 3$ predicts that the PISGM (as operationalized by PISGM) moderates the relationship between POSGM (as measured by SPGM minus PISGM) and audit quality (as measured by AudIndSpc, AFSize, AFees). As shown in the table, the results are presented separately for firm-years with a high PISGM (Panel A) versus firm-years with a low PISGM (Panel B), consistently with the discussions presented in section 3.1 (i.e., "Empirical models"). In both panels, we separately present the results for our three measures of audit quality, including audit industry specialization (AudIndSpc), audit firm size (AFSize), and audit fees (AFees), respectively. According to the results presented in Panel A, interestingly, the coefficients of POSGM (Coef. $=0.451,0.398,0.308)$ are positive and statistically significant at the 0.1 level ( $\mathrm{p}$-values $=0.007$, $0.049,0.071)$. This indicates that, for the firm-years with a high PISGM, the POSGM and audit quality are positively statistically associated. In other words, when there is high PISGM, the POSGM leads to higher audit quality - this is reflected in higher audit industry specialization, higher audit fees, and a larger audit firm. In contrast, in Panel B, the coefficients of POSGM are not statistically significant at the 0.1 level ( $\mathrm{p}$-values = $0.341,0.752,0.533)$. This suggests that, for the firm-years with low PISGM, the POSGM and audit quality are not statistically associated. An untabulated $F$ test suggests that

Table 3

The association of PISGM and audit quality

\begin{tabular}{|c|c|c|c|c|c|c|}
\hline \multirow{2}{*}{ Variable } & \multicolumn{2}{|c|}{$A u d I n d S p c$} & \multicolumn{2}{|c|}{ AFSize } & \multicolumn{2}{|c|}{ AFees } \\
\hline & Coefficient & Prob. & Coefficient & Prob. & Coefficient & Prob. \\
\hline PISGM & $0.058^{* *}$ & 0.044 & $0.012^{*}$ & 0.062 & $0.063^{* * *}$ & 0.008 \\
\hline Intercept & Yes & & Yes & & Yes & \\
\hline Control variables & Yes & & Yes & & Yes & \\
\hline EIndustry & Yes & & Yes & & Yes & \\
\hline ¿Year & Yes & & Yes & & Yes & \\
\hline Pseudo (adjusted) $R^{2}$ & 0.453 & & 0.694 & & 0.846 & \\
\hline LR/F (Prob.) & $799.932(0.000)$ & & $718.842(0.000)$ & & $81.567(0.000)$ & \\
\hline
\end{tabular}


Table 4

The moderating role of PISGM in the association between POSGM and audit quality

\begin{tabular}{|c|c|c|c|c|c|c|}
\hline \multicolumn{7}{|c|}{ Panel A: High PISGM } \\
\hline \multirow{2}{*}{ Variable } & \multicolumn{2}{|c|}{ AudIndSpc } & \multicolumn{2}{|c|}{ AFSize } & \multicolumn{2}{|c|}{ AFees } \\
\hline & Coefficient & Prob. & Coefficient & Prob. & Coefficient & Prob. \\
\hline POSGM & $0.451^{* * *}$ & 0.007 & $0.398^{* *}$ & 0.049 & $0.308^{*}$ & 0.071 \\
\hline Intercept & Yes & & Yes & & Yes & \\
\hline Control variables & Yes & & Yes & & Yes & \\
\hline EIndustry & Yes & & Yes & & Yes & \\
\hline$\sum$ Year & Yes & & Yes & & Yes & \\
\hline Adj./ Pseudo R ${ }^{2}$ & 0.447 & & 0.708 & & 0.889 & \\
\hline F stat/ LR (prob.) & $781.084(0.000)$ & & $765.011(0.000)$ & & $80.984(0.000)$ & \\
\hline \multicolumn{7}{|c|}{ Panel B: Low PISGM } \\
\hline & \multicolumn{2}{|c|}{ AudIndSpc } & \multicolumn{2}{|c|}{ AFSize } & \multicolumn{2}{|c|}{ AFees } \\
\hline & Coefficient & Prob. & Coefficient & Prob. & Coefficient & Prob. \\
\hline POSGM & -0.081 & 0.341 & 0.010 & 0.752 & 0.005 & 0.533 \\
\hline Intercept & Yes & & Yes & & Yes & \\
\hline Control variables & Yes & & Yes & & Yes & \\
\hline EIndustry & Yes & & Yes & & Yes & \\
\hline$\sum Y e a r$ & Yes & & Yes & & Yes & \\
\hline Adj./ Pseudo R ${ }^{2}$ & 0.302 & & 0.666 & & 0.811 & \\
\hline F stat/ LR (prob.) & $68.356(0.000)$ & & $700.776(0.000)$ & & $76.400(0.000)$ & \\
\hline
\end{tabular}

the association between POSGM and the audit quality measures in Panels A and B is significantly different at the 0.05 level. Collectively, the results show that, consistently with $H 3$, PISGM moderates the relationship between POSGM and audit quality.

\subsection{Additional analyses}

\subsection{Endogeneity Analysis}

SPGM, PISGM, and POSGM are probably associated with other variables that influence audit quality. To clarify, it could be expected that the size of companies simultaneously affects SPGM/PISGM/POSGM and audit quality. Under this condition, our findings - i.e., the impact of SPGM/PISGM/POSGM on audit quality — may stem from variables other than SPGM/PISGM/ POSGM. For this reason, the results may be potentially subject to endogeneity concerns.

To deal with the potential endogeneity, we use the propensity score matching methodology, following Shipman, Swanquist, and Whited (2017). In this regard, we regress the SPGM/PISGM/POSGM against the possible measurable determinants of SPGM/PISGM/POSGM, including size, the percentage of foreign ownership, the percentage of free float, the percentage of controlling shareholder ownership, and managerial ownership (see, for example, Beuthel, 2006; Schieber, 2002; Van der Elst, 2004). Using the predicted values of the regression, we match each company-year to a company-year with a similar/the closest predicted value in the same year-industry, consistently with past work (Hoi, Wu, \& Zhang, 2013). Finally, by providing a matched SPGM/PISGM/POSGM index, namely SPGM matched $/ P I S G M_{\text {matched }} / P O S G M_{\text {matched }}$ we re-examine the association between $S P G M_{\text {matched }}$ PISGM $M_{\text {matched }}$ POSGM $M_{\text {matched }}$ and audit quality.

Table 5 presents the findings of the endogeneity analysis. Panel A of the table shows the association between $S P G M_{\text {matched }} / P I S G M_{\text {matched }}$ and the three measures of audit quality. Furthermore, Panels B1 and B2 represent the association between POSGM matched and the three measures of audit quality in sub-samples with high versus low PISGM. The results show that, consistently with previous analyses, there is no significant (significant) association between $S P G M_{\text {matched }}\left(P I S G M_{\text {matched }}\right)$ and the audit quality measures. In this regard, the following results reveal that the association between POSGM matched and audit quality is significant only when the presence of PISGM is high. Taken together, the results show that our main findings are robust in relation to endogeneity concerns. 
Table 5

\section{Endogeneity analysis: Re-examination of $\mathrm{H} 1$ to $\mathrm{H3}$}

\begin{tabular}{|c|c|c|c|c|c|c|}
\hline \multicolumn{7}{|c|}{ Panel A: Re-examination of $\mathrm{H} 1$ [H2] } \\
\hline \multirow{2}{*}{ Variable } & \multicolumn{2}{|c|}{ AudIndSpc } & \multicolumn{2}{|c|}{ AFSize } & \multicolumn{2}{|c|}{ AFees } \\
\hline & Coefficient & Prob. & Coefficient & Prob. & Coefficient & Prob. \\
\hline$S P G M_{\text {matched }}\left[P I S G M_{\text {matched }}\right]$ & $0.019\left[0.041^{*}\right]$ & $0.243[0.051]$ & $-0.005\left[0.011^{*}\right]$ & $0.501[0.067]$ & $0.006\left[0.052^{* *}\right]$ & $0.462[0.013]$ \\
\hline Intercept & Yes & & Yes & & Yes & \\
\hline Control variables & Yes & & Yes & & Yes & \\
\hline$\sum$ Industry & Yes & & Yes & & Yes & \\
\hline ¿Year & Yes & & Yes & & Yes & \\
\hline Pseudo (adjusted) $\mathrm{R}^{2}$ & $0.387[0.400]$ & & $0.600[0.661]$ & & $0.829[0.838]$ & \\
\hline LR/F (Prob.) & $609.880(0.000)$ & $700.032(0.000]$ & $582.7163(0.000)$ & $697.963(0.000)]$ & $76.400(0.000)$ & {$[0.781(0.000)]$} \\
\hline \multicolumn{7}{|c|}{ Panel B: Re-examination of $H 3$} \\
\hline \multicolumn{7}{|c|}{ Panel B1: High PISGM } \\
\hline \multirow{2}{*}{ Variable } & \multicolumn{2}{|c|}{ AudIndSpc } & \multicolumn{2}{|c|}{ AFSize } & \multicolumn{2}{|c|}{ AFees } \\
\hline & Coefficient & Prob. & Coefficient & Prob. & Coefficient & Prob. \\
\hline POSGM $M_{\text {matched }}$ & $0.361^{* *}$ & 0.011 & $0.408^{* *}$ & 0.042 & $0.284^{*}$ & 0.076 \\
\hline Intercept & Yes & & Yes & & Yes & \\
\hline Control variables & Yes & & Yes & & Yes & \\
\hline EIndustry & Yes & & Yes & & Yes & \\
\hline ¿Year & Yes & & Yes & & Yes & \\
\hline Adj./ Pseudo R ${ }^{2}$ & 0.507 & & 0.719 & & 0.851 & \\
\hline F stat/ LR (prob.) & $\begin{array}{c}794.098 \\
(0.000)\end{array}$ & & $\begin{array}{c}895.275 \\
(0.000)\end{array}$ & & $79.863(0.000)$ & \\
\hline \multicolumn{7}{|c|}{ Panel B2: Low PISGM } \\
\hline & \multicolumn{2}{|c|}{ AudIndSpc } & \multicolumn{2}{|c|}{ AFSize } & \multicolumn{2}{|c|}{ AFees } \\
\hline & Coefficient & Prob. & Coefficient & Prob. & Coefficient & Prob. \\
\hline POSGM $M_{\text {matched }}$ & -0.086 & 0.333 & 0.013 & 0.673 & 0.008 & 0.438 \\
\hline Intercept & Yes & & Yes & & Yes & \\
\hline Control variables & Yes & & Yes & & Yes & \\
\hline EIndustry & Yes & & Yes & & Yes & \\
\hline ¿Year & Yes & & Yes & & Yes & \\
\hline Adj./ Pseudo R ${ }^{2}$ & 0.285 & & 0.689 & & 0.891 & \\
\hline F stat/ LR (prob.) & $69.073(0.000)$ & & $\begin{array}{c}705.112 \\
(0.000)\end{array}$ & & $79.920(0.000)$ & \\
\hline
\end{tabular}

\subsubsection{Regression with interactions analysis}

In the main analysis, to analyze how PISGM affects the association between POSGM and audit quality, we regressed the audit quality against POSGM in two subsamples, one with high and the other with low PISGM. In this section, we rerun the analysis by employing a regression with an interaction term. Specifically, we assess the association between the audit quality measures and the interaction of POSGM and PISGM. For more consistency between this analysis and the previous analysis, we use a dummy version of PISGM (PISGM $\left.{ }_{\text {dumm }}\right)$. Technically,
PISGM $M_{\text {dummy }}$ is coded as one (zero) for firm-years with PISGM greater than the median.

Table 6 reports the results. As shown in the table, the coefficients of "POSGM $\times$ PISGM $M_{\text {dummy }}$ " are significant for all of the four audit quality measures. Hence, consistently with the previous analysis, PISGM moderates the relationship between POSGM and audit quality measures.

\subsubsection{Untabulated analysis}

We also conduct three additional analyses to ascertain the robustness of our main results. First, since SPGM/PISGM/POSGM and audit quality are changing 
Table 6

Re-examination of H3: Regressions with interaction term

\begin{tabular}{|c|c|c|c|c|c|c|}
\hline \multirow{2}{*}{ Variable } & \multicolumn{2}{|c|}{ AudIndSpc } & \multicolumn{2}{|c|}{ AFSize } & \multicolumn{2}{|c|}{ AFees } \\
\hline & Coefficient & Prob. & Coefficient & Prob. & Coefficient & Prob. \\
\hline$P O S G M \times P I S G M_{d u m m y}$ & $0.198^{* * *}$ & 0.000 & $0.391^{* *}$ & 0.004 & $0.0491^{* *}$ & 0.013 \\
\hline Intercept & Yes & & Yes & & Yes & \\
\hline Base /Control variables & Yes & & Yes & & Yes & \\
\hline$\sum$ Industry & Yes & & Yes & & Yes & \\
\hline ¿Year & Yes & & Yes & & Yes & \\
\hline Pseudo (adjusted) $\mathrm{R}^{2}$ & 0.455 & & 0.691 & & 0.831 & \\
\hline LR/F (Prob.) & $800.482(0.000)$ & & $719.732(0.000)$ & & $80.348(0.000)$ & \\
\hline
\end{tabular}

over time (see, for example, Beuthel, 2006; Defond \& Zhang, 2014), our main findings may be driven by a time trend. To control this concern, we use a Fama-MacBeth regression, and re-estimate all of the main regressions. Second, to assure that persistent omitted variables do not affect the relationship between SPGM/PISGM/POSGM and audit quality, we re-run the main regressions, after adding firm fixed effects to the regressions. Third, since each quality measure may contain some measurement errors and may reflect a specific dimension of audit quality, we develop an aggregate audit quality measure through aggregation of dichotomous versions of our three audit quality measures. Then, we re-estimate all of the main regressions using this aggregate audit quality measure. In sum, untabulated findings reveal that our main results are not significantly sensitive to the similar time trend in SPGM/PISGM/POSGM and audit quality, persistent omitted variables, and aggregation of the audit quality measures.

\section{Conclusions}

Professional bodies generally encourage higher SPGM (e.g., U.S. Department of the Treasury, 2008; Institutional Shareholder Services, 2012). However, several theoretical studies (e.g., Jong, et al., 2006; Sjostrom, 2006; Stratling, 2003) question the value of this higher SPGM. In this research, we aimed to focus on one of the potential consequences of higher SPGM, i.e., higher audit quality. One of the main motivations for this focus comes from this fact that regulators are considering issuing recommendations to increase shareholder involvement in auditor selection and require all public companies to have a shareholder vote on it (e.g., Cunningham, 2017; Institutional Shareholder Services, 2015), and there is little empirical evidence on the beneficial effect of shareholder engagement on auditor appointments (e.g., Mayhew, 2017).

Theoretically, SPGM, as one of the corporate governance mechanisms (ISS 2016; SEC 2018a; SEC 2018b), can lead to better selection and supervision of external auditors (e.g., Tanyi \& Roland, 2017), and therefore higher audit quality. This is because higher SPGM reduces the influence of executive managers in the auditor selection and auditing processes, and therefore enhances audit quality (e.g., Mayhew \& Pike, 2004; Tanyi \& Roland, 2017). Furthermore, higher SPGM leads to a wider reflection of shareholders' interests in corporate governance processes and audit work (e.g., ISS 2016).

We find that, in general, there is no significant relationship between SPGM and audit quality. However, we reveal that, first, there is a positive significant association between PISGM and audit quality. Second, for companies with high PISGM, there is a significant positive relationship between POSGM and audit quality. This is consistent with the theoretical notion that institutional shareholders form a broad coalition that leads to more effective control of the company (Dressler \& Mugerman, 2021; Rossi et al., 2018). Specifically, multiple blocks of shareholders can coalesce around institutional shareholders to take more effective control, monitor, and evaluate the company and thus force the company to protect its shareholders (e.g., Bloch \& Hege, 2003).

The results have important implications for policymakers and regulators. For example, they may be helpful in developing an understanding of the relevance of higher SPGM for auditor behavior. Particularly, the results recommend that policymakers and regulators increase the beneficial effect of higher SPGM, by encouraging and facilitating the participation of institutional shareholders in general meetings. Furthermore, the findings provide further insights among the mixed evidence on the 
beneficial effects of SPGM (see for example, Banko et al., 2013) by revealing that the beneficial effects of SPGM are conditional to the level of institutional shareholder presence in general meetings.

We encourage readers to exercise some caution when using the results of this paper. This is because our results are based on an emerging market, where, on the one hand, the diversity of information channels/resources are not comparable to developed capital markets and information asymmetry between shareholders and managers is high (Hayaeian et al., 2021; Hesarzadeh, 2020; Su et al., 2014), and therefore shareholders have a relatively strong motivation for attending annual general meetings. On the other hand, there are not strong institutional settings that help shareholders to prevent the influences of managers in the auditing process and to monitor and control the audit quality; and thus the importance of shareholder engagement in the selection and supervision of auditors is high. Furthermore, the results must be interpreted in light of the following limitation. Our measures of SPGM and PISGM are based on shareholders' physical attendance, and therefore the measures may not fully reflect active attendance (i.e., engagement). As an interesting research question, we encourage future research to examine to what extent shareholders' physical attendance may reflect shareholders' active attendance.

\section{References}

Abbott, L.J., \& Parker, S., (2000). Auditor selection and audit committee characteristics. Auditing: A Journal of Practice and Theory 19 (2), 47-66. https://doi.org/10.2308/ aud.2000.19.2.47

Adeyemi, S., \& Fagbemi, T. (2010). Audit quality, corporate governance and firm characteristics in Nigeria. International Journal of Business and Management, 5 (5), 169-179. Retrieved from http://ir.unilag.edu.ng:8080/ xmlui/handle/123456789/2311

Advisory Committee on the Auditing Profession (ACAP). 2008. Final report of the advisory committee on the auditing profession to the U.S. Department of the Treasury. Author. Retrieved from https://www.treasury. gov/about/organizational-structure/offices/Documents/ final-report.pdf
Aggarwal, R., Saffi, P. A. C., \& Sturgess, J. (2015). The role of institutional investors in voting: Evidence from the securities lending market. The Journal of Finance 70 (5), 2309-2346. https://doi.org/10.1111/jofi.12284

Altman, E. (1983). Corporate financial distress: A complete guide to predicting, avoiding, and dealing with bankruptcy. New York: Wiley.

Amir, E., Guan, Y., \& Livne, G. (2018). Abnormal fees and timely loss recognition: A long-term perspective. Auditing: A Journal of Practice \& Theory. https://doi. org/10.2308/ajpt-52348

Apostolides, N. (2010). Exercising corporate governance at the annual general meeting. Corporate Governance. The International Journal of Business in Society, 10(2), 140-149. DOI 10.1108/14720701011035666

Apostolides, N., \& Boden, R. (2005). Cedric the Pig: Annual general meetings and corporate governance in the UK. Social Responsibility Journal, 1(1), 53-62. https:// doi.org/10.1108/eb045795

Attig, N., El Ghoul, S., \& Guedhami, O. (2009). Do multiple large shareholders play a corporate governance role? Evidence from East Asia. Journal of Financial Research, 32(4), 395-422. Retrieved from http://ssrn. $\mathrm{com} /$ abstract $=2352677$

Attig, N., El Ghoul, S., Guedhami, O., \& Rizeanu, S. (2013). The governance role of multiple large shareholders: Evidence from the valuation of cash holdings. Journal of Management \& Governance, 17(2), 419-451. DOI 10.1007/s10997-011-9184-3

Attig, N., Guedhami, O., \& Mishra, D. R. (2008). Multiple large shareholders, control contests, and implied cost of equity. Journal of Corporate Finance, 14(5), 721 737. https://doi.org/10.1016/j.jcorpfin.2008.08.008

Bae, G. S., Choi. S. U., \& Lee, J. E. (2019). Auditor industry specialization and audit pricing and effort. Auditing: A Journal of Practice \& Theory, 38(1), 51-75. https://doi.org/10.2308/ajpt-52039

Bae, K-H., Kang, J-K. \& Kim, J-M. (2002). Tunneling or value added? Evidence from Merger by Korean Business 
Group. Journal of Finance, 57(6), 2695-740. https:// doi.org/10.1111/1540-6261.00510

Banko, J., Frye, M., Wang, W., \& Whyte, A. M. (2013). Earnings management and annual general meetings: The role of managerial entrenchment. The Financial Review, 48, 259-282. https://doi.org/10.1111/fire. 12003

Barontini, R., \& Caprio, L. (2006). The effect of family control on firm value and performance: Evidence from Continental Europe. European Financial Management, 12(5), 689-723. https://doi.org/10.1111/j.1468036X.2006.00273.x

Barua, A., Raghunandan, K., \& Rama, D. V. (2017). Shareholder votes on auditor ratification and subsequent auditor dismissals. Accounting Horizons, 31(1), 129-139. https://doi.org/10.2308/acch-51512

Basu, N., Paeglis, I., \& Rahnamaei, M. (2016). Multiple blockholders, power, and firm value. Journal of Banking \& Finance, 66, 66-78. doi:10.1016/j.jbankfin.2016.01.001

Beasley, M. S., Carcello, J. V., Hermanson, D. R., \& Neal, T. L. (2009). The audit committee oversight process. Contemporary Accounting Research, 26(1), 65-122. https://doi.org/10.1506/car.26.1.3

Beattie, V., Fearnley, S., \& Brandt, R. (2000). Behind the audit report: A descriptive study of discussions and negotiations between auditors and directors. International Journal of Auditing, 4(2), 177-202. https:// doi.org/10.1111/1099-1123.00312

Bebchuk, L. A. (2005). The case for increasing shareholder power. (Discussion Paper No. 500) Harvard Law School Cambridge, MA. Retrieved from http://www.law.harvard. edu/programs/olin_center/papers/pdf/Bebchuk_500.pdf

Bebchuk, L. A., \& Cohen, A. (2005). The costs of entrenched boards. Journal of Financial Economics, 78(2), 409-433. https://doi.org/10.1016/j.jfineco.2004.12.006

Bebchuk, L. A., Cohen, A., \& Hirst, S., (2017). The agency problems of institutional investors. Journal of economic preservatives, 31(3), 89-102. DOI: 10.1257/ jep.31.3.89
Beck, M. J. \& Mauldin, E. G. (2014). Who's really in charge? Audit committee versus $\mathrm{CFO}$ power and audit fees. The Accounting Review, 89(6), 2057-2085. DOI: 10.2308/accr-50834

Bennedsen, M., \& Wolfenzon, D. (2000). The balance of power in closely held corporations. Journal of Financial Economics, 58(1-2), 113-139. https://doi.org/10.1016/ S0304-405X(00)00068-4

Beuthel, B. (2006). Electronic corporate governance: Online and virtual shareholder meetings and shareholder participation in Switzerland and Germany. University of St. Gallen, Zürich, Switzerland. Retrieved from https://www.e-helvetica.nb.admin.ch/api/download/ urn\%3Anbn\%3Ach\%3Abel-105265\%3Adis3195.pdf/ dis3195.pdf

Bhattacharya, N., Desai, H., \& Venkataraman, K. (2013). Does earnings quality affect information asymmetry? Evidence from trading costs. Contemporary Accounting Research, 30(2), 482-516. https://doi.org/10.1111/j.19113846.2012.01161.x

Bloch, F., \& Hege, U. (2003). Multiple shareholders and control contests. Retrieved from http://papers.ssrn. com/sol3/papers.cfm?abstract_id=2273211

Boubaker, S., Nguyen, P., \& Rouatbi, W. (2016). Multiple large shareholders and corporate risk-taking: Evidence from French family firms. European Financial Management, 22(4), 697-745. https://doi.org/10.1111/ eufm.12086

Brown, G. W., \& Cliff, M. T. (2004). Investor sentiment and the near-term stock market. Journal of Empirical Finance 11 (1), 1-27. https://doi.org/10.1016/j. jempfin.2002.12.001

Cai, J., Garbner, J. L., \& Walking, R. A. (2009). Electing directors. The Journal of Finance, 64(5), 2389-2421. Retrieved from https://onlinelibrary.wiley.com/doi/ pdf/10.1111/j.1540-6261.2009.01504.x

Cassell, C. A., Kleppe, T., \& Shipman, J. E. (2019). Should uninformed shareholders vote? Evidence from auditor ratification. doi:10.2139/ssrn.3113807 
Chen, P. F., He, S., Ma, Z., \& Stice, D. E. (2012). Qualified audit opinions and debt contracting. Working Paper, HKUST. Retrieved from http://www.kaa-edu. or.kr/online3/2013_1/1.\%20Derrald\%20Stice.pdf

Chen, S., Sun, S.Y.J., \& Wu, D. (2010). Client importance, institutional improvements, and audit quality in China: An office and individual auditor level analysis. The Accounting Review, 85 (1), 127-158. https:// doi.org/10.2308/accr.2010.85.1.127

Chrisman, J. J., Chua, J. H., \& Litz, R. A. (2004). Comparing the agency costs of family and non-family firms: Conceptual issues and exploratory evidence. Entrepreneurship Theory and Practice, 28(4), 335-354. https://doi.org/10.1111/j.1540-6520.2004.00049.x

Cohen, J., Krishnamoorthy, G., \& Wright, A. (2010). Corporate governance in the post-Sarbanes-Oxley era: Auditors' experiences. Contemporary Accounting Research, 27(3), 751-786. https://doi.org/10.1111/j.19113846.2010.01026.x

Cohen, J., Krishnamoorthy, G., \& Wright, A.M. (2002). Corporate governance and the audit process. Contemporary Accounting Research, 19(4), 573-594. https://doi.org/10.1506/983M-EPXG-4Y0R-J9YK

Cunningham, L. M. (2017). Auditor ratification: Can't get no (dis)satisfaction. Accounting Horizons, 31(1), 159-175. https://doi.org/10.2308/acch-51652

Daniel, A. (2010). Balance of power between shareholders and the board in corporate governance. Retrieved from https://ssrn.com/abstract=1612962

Dao, M., Raghunandan, K., \& Rama, D.V. (2012). Shareholder voting on auditor selection, audit fees, and audit quality. The Accounting Review, 87(1), 149-171. https://doi.org/10.2308/accr-10159

DeAngelo, L. (1981). Auditor independence, "low-balling" and disclosure regulation. Journal of Accounting and Economics, 3, 113-127. https://doi.org/10.1016/01654101(81)90009-4

Dhaliwal, D. S., Lamoreaux, P. T., Lennox, C. S., \& Mauler, L. M. (2014). Management Influence on
Auditor Selection and Subsequent Impairments of Auditor Independence during the Post-SOX Period. Contemporary Accounting Research, 32(2), 575-607. doi: 10.1111/1911-3846.12079

Dressler, E., \& Mugerman, Y. (2021). Doing the Right Thing? The Voting Power Effect and Institutional Shareholder Voting. SSRN Electronic Journal. doi:10.2139/ ssrn. 3785420

Engel, E., Hayes, R. M., \& Wang, X. (2010). Audit committee compensation and the demand for monitoring of the financial reporting process. Journal of Accounting and Economics, 49 (1-2), 136-154. https://doi.org/10.1016/j. jacceco.2009.08.001

European Commission. (2010). Green Paper, Audit Policy: Lessons from the Crisis, $\operatorname{COM}(2010) 561$ final. Brussels. Retrieved from https://www.europarl. europa.eu/meetdocs/2009_2014/documents/com/ com_com(2010)0561_/com_com(2010)0561_en.pdf

European Union. (2006). Directive 2006/43/EC of the European Parliament and of the Council of 17 May 2006 on statutory audits of annual accounts and consolidated accounts, amending Council Directives 78/660/EEC and 83/349/EEC and repealing Council Directive 84/253/ EEC. Official Journal of the European Union, 2006, L 157/87. Retrieved from https://eur-lex.europa.eu/ legal-content/EN/TXT/?uri=CELEX\%3A32006L0043

European Union. (2020). Shareholder rights directive. Retrieved from https://eur-lex.europa.eu/summary/ EN/uriserv:133285

Faleye, O. (2007). Classified boards, firm value, and managerial entrenchment. Journal of Financial Economics, 83(2), 501-529. https://doi.org/10.1016/j. jfineco.2006.01.005

Federal Trade Commission - FRC. (2003). Letter to the Honorable Ward Crutchfield, from the Office of the Chairman. Retrieved from http://www.ftc.gov/be/ v030009.shtm

Fischer, P. E., Gramlich, J. D., Miller, B. P., \& White, H. D. (2009). Investor perceptions of board performance: 
Evidence from uncontested director elections. doi:10.2139/ ssrn. 928843

Fontaine, R., S. B. Letaifa, \& D. Herda. (2013). An interview study to understand the reasons clients change audit firms and the client's perceived value of the audit service. Current Issues in Auditing, 7(1), A1-A14. DOI: $10.2308 /$ ciia- 5047

Gibbins, M., McCracken, S. A. \& Salterio, S. E. (2005). Negotiations over accounting issues: The congruency of audit partner and chief financial officer recalls. Auditing: A Journal of Practice \& Theory, 24(s-1), 171-93. DOI: 10.2308/aud.2005.24.s-1.171

Gibbins, M., Salterio, S., \& Webb, A. (2001). Evidence about auditor-client management negotiation concerning client's financial reporting. Journal of Accounting Research, 39(3), 535-63. https://doi.org/10.1111/1475-679X.00027

Gompers, P. A., Ishii, J., \& Metrick, A. (2009). Extreme governance: An analysis of dual-class firms in the United States. Review of Financial Studies, 23(3), 1051-1088. https://doi.org/10.1093/rfs/hhp024

González, G. P., Guzman, A., Prada, F. J., \& Trujillo, M.-A. (2013). A waste of time or effective corporate governance bodies? doi:10.2139/ssrn.2395053

Gotti, G., Han, S., Higgs, J.L. \& Kang, T. (2012). Managerial stock ownership, analyst coverage, and audit fee. Journal of Accounting, Auditing \& Finance, 27(3), 412-37. https://doi.org/10.1177/0148558X11409158

Hayaeian, S., Hesarzadeh, R., \& Abbaszadeh, M. R. (2021). The impact of knowledge management strategies on the relationship between intellectual capital and innovation: evidence from SMEs. Journal of Intellectual Capital, ahead-of-print(ahead-of-print). doi:10.1108/ jic-07-2020-0240

Hermanson, D. R., Krishnan, J., \& Ye, Z. (2009). Adverse Section 404 opinions and shareholder dissatisfaction toward auditors. Accounting Horizons, 23(4), 391-409. https://doi.org/10.2308/acch.2009.23.4.391

Hesarzadeh, R. (2019). Are the individual and collective roles of financial reporting quality measures the same?
Evidence in the context of information uncertainty. Spanish Journal of Finance and Accounting, 48(2), 160202. https://doi.org/10.1080/02102412.2018.1469858

Hesarzadeh, R. (2020). Regulatory oversight and managerial ability. Eurasian Business Review. Forthcoming. doi:10.1007/s40821-020-00150-0

Hesarzadeh, R., \& Bazrafshan, A. (2019). CEO ability and regulatory review risk. Managerial Auditing Journal, 34(5), 571-601.

Hesarzadeh, R., \& Rajabalizadeh, J. (2020). Does securities commission oversight reduce the complexity of financial reporting? Revista de Contabilidad, 23(1), 1-17. DOI: https://doi.org/10.6018/rcsar.389791

Hilzenrath, D. S. (2001). After Enron, new doubts about auditors. The Washington Post. December 5. A01.

Hoi, C., Wu. K., \& Zhang. H. (2013). Is corporate social responsibility (CSR) associated with tax avoidance? Evidence from Irresponsible CSR Activities. The Accounting Review, 88, (6), 2025-2059.

Holland, K. V., Lim, C., \& Yi, I. (2021). Shareholder Meetings Uncertainty: Evidence from the Options Market. SSRN Electronic Journal. doi:10.2139/ssrn.3765575

Hu, Y., \& Izumida, S. (2008). Ownership concentration and corporate performance: A Causal Analysis with Japanese Panel Data. Corporate Governance: An International Review, 16(4), 342-358.

Institutional Shareholder Services (ISS). (2012). 2012 U.S. Proxy voting summary guidelines. Available at: https:// www. issgovernance.com/file/files/2012USSummaryGuidelines. pdf

Institutional Shareholder Services (ISS). (2015). International public fund proxy voting guideline updates. Available at: https://www.issgovernance.com/file/policy/1_2015public-fund-international-policy-updates.pdf

Institutional Shareholder Services (ISS). (2016). International public fund proxy voting guideline updates. Available at: https://www.issgovernance.com/file/policy/2016public-fund-international-proxy-voting-guidelines.pdf 
Islamic Consultative Assembly. (1979). Commercial Law. Available at http://https://rc.majlis.ir/fa/law/ show/92349 (with Persian).

Jong, A., Mertens, G., \& Roosenboom, P. (2006). Shareholders' voting at general meetings: Evidence from the Netherlands. Journal of Management and Governance, 10, 353-380.

Kahneman, D., \& Tversky, A. (1979). Prospect theory: An analysis of decision under risk. Econometrica, 47(2), 263-292.

Kaniel, R., Saar, G., \& Titman, S. (2008). Individual investor trading and stock returns. The Journal of Finance, 63(1), 273-310.

KPMG. (2004). Oversight of auditors: Audit committee roundtable highlights. Audit Committee Insights. Montvale, NJ: KPMG.

Krishnan, J., \& Ye, Z. (2005). Why some companies seek shareholder ratification on auditor selection. Accounting Horizons, 19, 237-254.

Latham, M. (2003). Democracy and infomediaries. Corporate Governance: An International Review, 11(2), p. 91-101.

Lev, B. (2002). Too gray for its own good. Wall Street Journal, 22, A20.

Liu, H., Cullinan, C. P., \& Zhang, J. (2018). Modified audit opinions and debt contracting: Evidence from China. Asia-Pacific Journal of Accounting \& Economics, 27(2), 218-241.

Liu, L., Raghunandan, K., \& Rama, D. (2009). Financial restatements and shareholder ratifications of the auditor. Auditing: A Journal of Practice and Theory, 28(1), 225-240.

Louis, H. (2005). Acquirers' abnormal returns and the non-Big 4 auditor clientele effect. Journal of Accounting and Economics, 40, 75-99.

Lund, D. S. (2019). Nonvoting shares and efficient corporate governance. Stanford Law Review, 71 (Forthcoming).
Mansi, S. A., Maxwell, W. F., \& Miller, D. P. (2004). Does auditor quality and tenure matter to investors? Evidence from the bond market. Journal of Accounting Research, 42(4) 755-793. https://doi.org/10.1111/j.1475679X.2004.00156.x

Mashayekhi, B, \& Mashayekh, S. (2008). Development of accounting in Iran. The International Journal of Accounting, 43(1), 66-86.

Mayhew, B. W. (2017). Introduction and commentary on ratification research forum. Accounting Horizons, 31(1) 125-128. https://doi.org/10.2308/acch-10519

Mayhew, B. W., \& Pike, J. E. (2004). Does investor selection of auditors enhance auditor independence? The Accounting Review, 79(3), 797-822. https://doi. org/10.2308/accr.2004.79.3.797

Minutte-Meza, M. (2013). Does auditor industry specialization improve audit quality? Journal of Accounting Research, 51(4), 779-817.

O'Connor, Sean M. (2002). The Inevitability of Enron and the impossibility of 'auditor independence' under the current audit system. Retrieved from https://ssrn. com/abstract=303181 or http://dx.doi.org/10.2139/ ssrn.303181

Park, B. (2018). Audit committees and managerial influence on audit quality: "Voluntary" versus "Mandatory" approach to corporate governance. Australian Accounting Review, 29(1), 266-280. https://doi.org/10.1111/auar.12263

Patterson, E. R., Smith, R. J., \& Tiras, S. L. (2019). The effects of auditor tenure on fraud and its detection. The Accounting Review, 94(5), 297-318. https://doi. org/10.2308/accr-52370

Paytakhti Oskooe, S. A. (2011). The Iran stock market: Efficiency, volatility and links to the international oil market. (Thesis). Kingston University. Retrieved from http://eprints.kingston.ac.uk/id/eprint/22360

PCAOB, 2010. Auditing Standard No. 14: Evaluating audit results. PCAOB release No. 2010-004. 
Porter, B., O ' hO' gartaigh, C., \& Baskerville, R. (2012). Audit expectation-performance gap revisited: evidence from New Zealand and the United Kingdom part 1: the gap in New Zealand and the United Kingdom in 2008. International Journal of Auditing, 16 (2), 101-129.

Proctor, G., Miles, L. (2003). Corporate governance. London: Cavendish Publishing Limited

Reputation Institute. (2015). Defining and managing reputation risk: A framework for risk managers. retrieved from: https://www.reputationinstitute.com/sites/ default/files/pdfs/Defining-and-Managing-ReputationRisk-2015.pdf

Rossi, F., J. R. Barth, \& R. J. Cebula. (2018). Do shareholder coalitions affect agency costs? Evidence from Italian-listed companies, Research in International Business and Finance, 46, 181-200.

Ruhnke, K., \& Schmidt, M. (2014). The audit expectation gap: existence, causes, and the impact of changes. Accounting and Business Research, 44(5), 572-601. doi :10.1080/00014788.2014.929519

Sajadi. S. H., Farazmand, H. Gorbani, H. s., (2012). The Effect of Auditor Tenure on Audit Quality. Journal of Accounting Advances. Vol. 4, No. 4, pp. 81-109.

Saxon, G. O. (1966). Annual Headache: The Stockholders Meeting. Harvard Business Review, 44, 132-137.

Schauer, P. C. (2001). The effects of industry specialization on audit Quality: An examination using bid-ask spreads. Working Paper, Bowling Green State University.

Schieber, D. (2002). Auswirkungen des Interneteinsatzes auf die Präsenz bei Hauptversammlungen. in Zetzsche, D. (ed.) Die Virtuelle Hauptversammlung, Berlin, Germany, Erich Schmidt Verlag.

Securities and Exchange Commission (SEC). (2018a). Statement Announcing SEC Staff Roundtable on the Proxy Process. (July 30). Washington, DC: SEC.

Securities and Exchange Commission (SEC). (2018b). Roundtable on the Proxy Process. (November 15). Washington, DC: SEC.
Securities and Exchange Organization. (2007a). The Regulations Governing the Trusted Auditing Firms of the Securities and Exchange Organization. Retrieved from http://www.rdis.ir/.

Securities and Exchange Organization. (2007b), The Regulations on Disclosure of Information by The Companies Registered with the Organization. Retrieved from http:// www.rdis.ir/.

Seeger, A. M. (2002) Die Online Hauptversammlung, Wiesbaden, Germany, Deutscher Universitätsverlag.

Shipman. J. E., Swanquist. Q. T., \& Whited. R. L.. (2017). Propensity score matching in accounting research. The Accounting Review, 92, 213-244.

Shleifer, A. \& R.W. Vishny. (1986). Large shareholders and corporate control. Journal of Political Economy, 94(31), 461-488.

Sjostrom, W. K., (2006). The case against mandatory annual director elections and shareholders' meetings. Tennessee Law Review, 74,199-239.

Stewart, J., \& Munro, L. (2007). The Impact of Audit Committee Existence and Audit Committee Meeting Frequency on the External Audit: Perceptions of Australian Auditors. International Journal of Auditing, 11(1), 51-69.

Strand, T. (2013). The Owners and the Power: Insights from annual general meetings. PhD Series 25.2012. The $\mathrm{PhD}$ School of Economics and Management

Stratling, R. (2003). General Meetings: a dispensable tool for corporate governance of listed companies? Corporate Governance: An International Review, 11(1),74-82.

Su. W., Peng. M. W., Tan. W., \& Cheung. Y. L. (2014). The signaling effect of corporate social responsibility in Emerging Economies. Journal of Business Ethics, 92(4), $1-25$.

Swieringa, R. J., \& Weick, K. E. (1982). An assessment of laboratory experiments in accounting. Journal of Accounting Research, 20, 56-101. 
Tanyi, P. N., \& K. C. Roland. (2017). Market reaction to auditor ratification vote tally. Accounting Horizons, 31(1), 141-157.

Tanyi, P., \& Cathey, J. (2020). Why do firms seek shareholders ratification of the independent audit function? The case of foreign cross-listed companies in the United States. International Journal of Auditing, 24(1), 24-36.

Turley, S. \& Zaman, M. (2004). The corporate governance effects of audit committees. Journal of Management \& Governance, 8(3), 305-32.
U.S. Department of the Treasury (DoT). (2008). Report of the advisory committee on the auditing profession to the U.S. Department of Treasury. Washington, D.C.: U.S. Department of Treasury.

Van der Elst, C. (2004). Attendance of shareholders and the impact of regulatory corporate governance reforms: An empirical assessment of the situation in Belgium. European Business Organization Law Review, 5(3), 471-510.

Vanstraelen, A., Schelleman, C., Meuwissen, R., \& Hofmann, I. (2012). The audit reporting debate: 
seemingly intractable problems and feasible solutions. European Accounting Review, 21(2), 193-215.

Velury, U., Reisch, T. J., \& O’Reilly, M. D. (2003). Institutional ownership and the selection of industry specialist auditors. Review of Quantitative Finance and Accounting, 21(1), 35- 48.

Venkataraman, R., Weber, J., \& Willenborg, M. (2008). Litigation risk, audit quality, and audit fees: Evidence from initial public offerings. The Accounting Review, 83, 1315-1345.

Villalonga, B., Amit, R., Trujillo, M.-A., \& Guzmán, A. (2015). Governance of family firms. Annual Review of Financial Economics, 7(1), 635-654.

Yermack, D. (2010). Shareholder voting and corporate governance. Annual Review of Financial Economics, 2(1), 103-125.

\section{Appendix A \\ Research instruments}

In this study, the variables are defined (empirically measured) as follows:

- Audit quality includes AudIndSpc, AFSize, and AFees. These measures are calculated as follows.

- AudIndSpc is the auditor's expertise in the industry and measured by the market share of the audit firms. Specifically, if the market share of the audit firm is higher (lower) than $1.2 \times(1 \div$ the number of companies in the industry-year), we coded the variable as one (zero). The market share is the total assets of all clients of each audit firm in an industry-year divided by the total assets of all companies in the same industry-year (Source: Rahavard-e-Novin).

- AFSize is a dichotomous variable coded as one if the company is audited by a big audit firm, and zero otherwise (Source: Rahavard-e-Novin).
- AFees is the natural logarithm of audit fees (Source: Rahavard-e-Novin).

- SPGM is the percentage of the ownership represented by the shareholders who attend the general meeting (Source: CODAL, Report on Summary of General Meetings Decisions).

- PISGM is the percentage of the ownership represented by the institutional shareholders who attend the general meeting (Source: CODAL, Report on Summary of General Meetings Decisions).

- POSGM is the percentage of the ownership represented by the non-institutional shareholders who attend the general meeting

- Ach (as a control variable) is a dichotomous variable coded as one if the auditor is changed and zero otherwise (Source: Rahavard-e-Novin).

- Size (as a control variable) is the size of the company and is equal to the logarithm of the total assets (Source: Rahavard-e-Novin).

- Lev (as a control variable) is the total liabilities divided by total assets (Source: Rahavard-e-Novin).

- Inst (as a control variable) is the percentage of institutional ownership (i.e., the percentage of shares held by banks, insurance companies, pension funds, and investment companies) (Source: Rahavard-e-Novin).

- Gov (as a control variable) is the percentage of shares held by the government (Source: Rahavard-e-Novin).

- Man (as a control variable) is the percentage of shares held by the managers (Source: Rahavard-e-Novin).

- Loss (as a control variable) is a dichotomous variable coded as one if net income is negative, and zero otherwise (Source: Rahavard-e-Novin).

- INB (as a control variable) is the independence of the board of directors, calculated as the number of non-executive directors divided by the total number of directors (Source: Rahavard-e-Novin).

- ROA (as a control variable) is the net income divided by total assets (Source: Rahavard-e-Novin). 
- BTM (as a control variable) is the book value of equity divided by the market value of equity (Source: Rahavarde-Novin).

- Alt (as a control variable) is the Altman (1983) financial distress score. The score is coded as one if it is greater than the median and zero otherwise (Source: Rahavard-e-Novin).

- Gro (as a control variable) is the percentage of sales growth (Source: Rahavard-e-Novin).

- FIN (as a control variable) is a dichotomous variable coded as one if there is an equity/debt issuance (Source: Rahavard-e-Novin).

- FS (as a control variable) is the foreign sales divided by total assets (Source: Rahavard-e-Novin).

- Seg (as a control variable) is the natural logarithm of the number of segments (Source: Rahavard-e-Novin).

- $\sum$ Industry reflects industry fixed effects (Source: Rahavard-e-Novin).

- $\sum$ Year reflects year fixed effects (Source: Rahavard-e-Novin).

\section{Conflicts of interest:}

The authors have no conflict of interest to declare

\section{Copyrights:}

RBGN owns the copyrights of this published content

\section{Plagiarism analysis}

RBGN performs plagiarism analysis on all its articles at the time of submission and after approval of the manuscript using the iThenticate tool.

\section{Authors:}

1. Ameneh Bazrafshan, Ph.D in Accounting, Imam Reza International University, Mashhad, Iran.

E-mail: Bazrafshan@imamreza.ac.ir

2. Akram Banaiy, MS in Accounting, Imam Reza International University, Mashhad, Iran.

E-mail: Akram.Banaiy@imamreza.ac.ir

3. Vajiheh Bazrafshan, MS in Auditing, Imam Reza International University, Mashhad, Iran.

E-mail: v.bazrafshan@imamreza.ac.ir

\section{Authors' Contributions}

1. Ameneh Bazrafshan: Definition of research problem; Development of hypotheses or research questions (empirical studies); Development of theoretical propositions (theoretical work); Theoretical foundation/literature review; Definition of methodological procedures; Data collection; Statistical analysis; Analysis and interpretation of data; Critical revision of the manuscript; Manuscript writing.

2. Akram Banaiy: Definition of research problem; Development of hypotheses or research questions (empirical studies); Data collection.

3. Vajiheh Bazrafshan: Development of theoretical propositions (theoretical work); Data collection; Manuscript writing. 